\title{
PENGARUH KUALITAS PELAYANAN INTI DAN KUALITAS PELAYANAN PERIFERAL TERHADAP WORD OF MOUTH MELALUI KEPUASAN KONSUMEN SEBAGAI VARIABEL INTERVENING (STUDI PADA BUS TRANS SEMARANG)
}

\section{Devi Fitriani}

Soedarmadi

Fakultas Ekonomi Universitas Semarang

Diterima: Mei 2019, Disetujui: Juni 2019, Dipublikasikan: Juli 2019

\begin{abstract}
Word of mouth has great power that has an impact on cutomers purchasing behavior. customers will assess high quality if the perceived value meets their expectations besides that as the quality of service increases there will be a willingness to recommend to others, the company must maitain and maintain its customers by paying attention to two factors such as core service quality and pheriferal service quality. The purpose of this research is to analyze the influence of core service quality and pheriferal service quality on customer satisfaction and its impact on word of mouth.

The population of this study is all cutomers at Bus Trans Semarang within the last six months with unknow amount. Samples taken were 99 people. The sampling technique was purposive sampling. Data analysis using multiple linear regression, $t$ test, coefficient of determination and path analysis.

The results of the study show that there is a positive and significant influence between core service quality on customer satisfaction. There is a positive and significant influence between pheriperal service quality on customer satisfaction. There is a positive and significant influence between core service quality on word of mouth. there is a positive and significant influence between pheriferal service quality on word of mouth. there is a positive and significant influence between customer satisfaction on word of mouth
\end{abstract}

Keywords : Core Service Quality, Pheriferal Service Quality, Customers Satisfacttion and Word of Mouth 


\begin{abstract}
ABSTRAK
Word of mouth memiliki kekuatan besar yang berdampak pada perilaku pembelian konsumen. konsumen akan menilai kualitas tinggi jika nilai yang dirasakan memenuhi harapan mereka selain itu seiring meningkatnya kualitas layanan akan ada kemauan untuk merekomendasikan kepada orang lain, maka perusahaan harus tetap menjaga dan mempertahankan para konsumennya dengan cara meningkatkan kepuasan dan word of mouth dengan cara memberikan yang terbaik kepada konsumen dengan memperhatikan dua faktor yaitu kualitas pelayanan inti dan kualitas pelayanan periferal. Tujuan diadakannya penelitian ini : menganalisis pengaruh kualitas pelayanan inti dan kualitas pelayanan periferal terhadap kepuasan konsumen dan dampaknya kepada word of mouth.
\end{abstract}

Populasi penelitian ini adalah seluruh pengguna Bus Trans Semarang dalam kurun waktu enam bulan terakhir dengan jumlah tidak diketahui secara pasti. Sampel yang diambil sejumlah 99 orang. teknik pengambilan sampel adalah purposive sampling. Analisis data menggunakan regresi linier berganda, uji t, koefisien determinasi dan analisis jalur.

Hasil penelitian menunjukkan bahwa terdapat pengaruh positif dan signifikan antara kualitas pelayanan inti terhadap kepuasan konsumen. Terdapat pengaruh positif dan signifikan antara kualitas pelayanan periferal terhadap kepuasan konsumen. Terdapat pengaruh positif dan signifikan antara kualitas pelayanan inti terhadap word of mouth. Terdapat pengaruh positif dan signifikan antara kualitas pelayanan periferal terhadap word of mouth. Terdapat pengaruh positif dan signifikan antara kepuasan konsumen terhadap word of mouth.

Kata Kunci : Kualitas Pelayanan Inti, Kualitas Pelayanan Periferal, Kepuasan Konsumen, Word of Mouth.

\title{
PENDAHULUAN
}

\section{Latar Belakang}

Populasi dan mobilitas manusia saat ini semakin mengalami peningkatan, kota-kota besar seperti kota semarang masih menjadi tujuan favorit bagi para pendatang untuk mencari pekerjaan. Akibatnya, kondisi kota menjadi semakin padat, macet dan salah satu akibatnya adalah akan meningkat pula penggunaan sarana transportasi, Sebab transportasi umum merupakan sarana angkutan untuk masyarakat kecil dan menengah agar dapat melaksanakan kegiatannya sesuai dengan tugas dan fungsinya. Pengguna angkutan umum ini bervariasi, mulai dari buruh, ibu rumah tangga, mahasiswa, pelajar, dan lain-lain. Transportasi umum, khususnya angkutan orang seperti bus, taxi, angkot yang diatur dalam Keputusan 
Menteri Perhubungan Nomor KM 68 Tahun 1993 yang telah diperbaharui menjadi Keputusan Menteri Perhubungan Nomor KM 84 Tahun 1999 tentang Penyelenggaraan Angkutan Orang di Jalan Dengan Kendaraan Umum, secara struktural dipisahkan dalam tiga kepentingan yaitu kepentingan pengguna jasa, penyedia jasa dan pemerintah.

Sehingga hal yang terjadi membuat para pelaku usaha baik produk maupun jasa berlomba-lomba merebut hati pasar sasarannya. bisa kita lihat dengan semakin beragamnya macam jenis barang ataupun jasa yang ditawarkan memberi peluang pada kita untuk bebas memilih barang atau jasa yang dikehendaki dan bebas untuk membandingkan produk atau jasa yang ada beserta faktor yang berhubungan dengan produk tersebut seperti kualitas produk dan pelayanan, maka dari itu pencarian informasi sangatlah penting untuk memperoleh produk yang berkualitas yang dapat memenuhi kebutuhan dan keinginan masyarakat. Biasanya konsumen akan mencari informasi tersebut ke sumber-sumber yang dapat memberikan informasi yang dibutuhkan. Rekomendasi dari orang lain berpengaruh sangat besar, apalagi bila rekomendasi itu berasal dari orang yang dikenal. Iklan dalam bentuk rekomendasi word of mouth dari orang yang dikenal dan dipercaya masih menjadi sumber iklan paling dipercaya oleh konsumen. Menurut laporan survei global yang dirilis oleh nilsen tahun 2015 menyatakan bahwa khususnya di asia tenggara $88 \%$ konsumen menempatkan tingkat tertinggi kepercayaan mereka pada rekomendasi word of mouth dari orang yang mereka kenal. Konsumen filipina memimpin dengan $91 \%$.

Kepercayaan pada word of mouth meningkat paling tinggi pada konsumen vietnam yang naik 8 poin mnjadi $89 \%$, serupa dengan konsumen indonesia yang naik 4 poin menjadi $89 \%$, diikuti oleh konsumen malaysia dengan $86 \%$ naik 1 poin, konsumen singapura dengan $83 \%$ turun 2 poin dan konsumen thailand dengan $82 \%$ meningkat 3 poin. Dari hasil survei tersebut membuat persaingan pada para pelaku bisnis untuk menjadi bergairah dalam memberikan pelayanan kepada konsumen bertujuan untuk memberikan rasa puas terhadap pelanggan dan dapat memiliki daya saing dibanding kompetitor. Dalam menciptakan kepuasan pelanggan perusahaan harus dapat meningkatkan kualitas layanannya, semakin 
baik keunggulan layanannya maka akan semakin tinggi pula kepuasan pelanggan terhadap perusahaan tersebut. Menurut survei pelayanan Ditjen SDPPI 2017 telah menyatakan bahwa indeks integritas pelayanan publik menunjukkan adanya kenaikan Indeks Kepuasan Masyarakat (IKM) sebesar 0,87\% pada tahun 2016 jika dibandingkan dengan IKM tahun 2015. Persentase kenaikan yang terbesar terdapat pada unit layanan sertifikasi alat dan perangkat telekomunikasi sebesar 2,07\% maka semua unit layanan publik di lingkungan ditjen SDPPI sedikit lagi bisa melewati passing grade mutu pelayanan A dengan kinerja pelayanan sangat baik yaitu nilai IKM diatas $81,25 \%$. Dari survei tersebut bisa disimpulkan bahwa pelayanan yang baik akan mempengaruhi tingkat kepuasan konsumen.

Seperti halnya survei kepuasan pelanggan yang dilakukan oleh direktorat pengembangan EPSE 2017, lembaga kebijakan pengadaan barang/jasa pemerintah (LKPP) menyatakan bahwa pada tahun 2016 sebanyak 87,04\% responden menyatakan puas terhadap media penyampaian pemasalahan, sebanyak $83,33 \%$ menyatakan puas terhadap kecepatan penanganan permasalahan, sebanyak 94,44\% responden menyatakan puas terhadap kualitas penyelesaian permasalahan, dan sebanyak 90,74\% responden menyatakan puas terhadap kesesuaian penyelesaian, Maka dapat disimpulkan bahwa Kepuasan konsumen menjadi indikator penting dalam sukses atau tidaknya sebuah pelayanan publik dalam memberikan pelayanan prima pada penggunanya.

Dalam menciptakan kepuasan pelanggan, perusahaan harus dapat meningkatkan kualitas layanannya (service quality). Kepuasan pelanggan dapat diciptakan melalui kualitas layanan yang diberikan oleh perusahaan kepada para pelanggannya. Semakin baik keunggulan layanannya, akan semakin tinggi pula kepuasan pelanggan terhadap perusahaan tersebut. ( Hapsari, dkk 2016)

Menurut Sam liu, dkk (2016) berpendapat bahwa konsumen akan menilai kualitas tinggi jika nilai yang dirasakan memenuhi harapan mereka selain itu seiring meningkatnya kualitas layanan maka akan ada kemauan untuk merekomendasikan kepada orang lain. Menurut Yildiz (2017) menyatakan bahwa kualitas pelayanan merupakan indikator penting bagi perusahaan untuk bersaing, oleh karena itu mereka harus menawarkan konsumen layanan yang berkualitas 
tinggi karena pelanggan yang puas akan mengacu pada perilaku konsumen memberi tahu orang lain tentang pengalaman mereka dengan produk dan jasa.

Sedangkan Menurut Pappachan (2016) menyatakan bahwa kepuasan konsumen berpengaruh positif terhadap word of mouth, salah satu keunggulan kompetitif yang dapat diciptakan perusahaan adalah memfokuskan bisnisnya pada kepuasan pelanggan, apabila pelayanan yang diterima atau dirasakan sesuai dengan yang diharapkan, maka kualitas pelayanan dipersepsikan baik dan memuaskan, sehingga melalui kepuasan itu konsumen akan melakukan pembelian jasa atau memutuskan untuk menggunakan jasa dan pada akhirnya akan merekomendasikan hal itu kepada orang lain.

Menurut Kotler dan Keller (2009:512) mendefinisikan word of Mouth adalah kegiatan pemasaran melalui perantara orang ke orang disekitarnya baik secara lisan, tulisan, maupun alat komunikasi elektronik yang berhubungan dengan pengalaman pembelian jasa atau pengalaman menggunakan produk atau jasa. Word of mouth memiliki kekuatan besar yang berdampak pada perilaku pembelian konsumen. Rekomendasi dari teman yang sudah dipercaya, asosiasi, dan konsumen lain berpotensi untuk lebih dipercaya dibanding dari sumber komersil, seperti iklan dan sales people. Sebagian besar word of mouth terjadi secara alami, konsumen mulai dengan membicarakan sebuah merk yang mereka gunakan kepada orang lain. (Kotler \& Amstrong, 2012;139)

Penelitian ini dilakukan pada Bus Trans Semarang Pengelola dari Bus Trans Semarang adalah Dinas Perhubungan kota Semarang, menurut BLU UPTD Terminal Mangkang 2017, Bus Trans Semarang merupakan sebuah sistem transportasi bus cepat, ekonomis dan ber-AC (Air Conditioner) di seputar Kota Semarang. Bus Trans Semarang merupakan salah satu bagian dari program penerapan Bus Rapid Transit (BRT) yang dicanangkan Departemen Perhubungan, BRT Trans Semarang mulai beroperasi pada tahun 2010. Koridor I yaitu Mangkang-Penggaron mulai beroperasi pada tanggal 1 Oktober 2010, Koridor II yaitu Terboyo-Sisemut mulai beroperasi pada tanggal 1 Oktober 2012, Koridor IV yaitu Cangkiran-Bandara A.Yani baru mulai beroperasi pada tanggal 1 Desember 
2013, Koridor III yaitu Tanjung Mas-Akpol baru mulai beroperasi tanggal 1 November 2014.

Koridor V dan VI diluncurkan pada tanggal 31 Maret 2017 di Kampus Universitas Diponegoro. Koridor V merupakan Koridor terpanjang dalam operasional Trans Semarang, dengan trayek Perumahan Bukit Kencana Jaya hingga PRPP, dan menggunakan armada bantuan Kemenhub anggaran 2016 (Armada yang sama seperti TransJogja). Sementara koridor VI beroperasi dengan trayek Universitas Diponegoro hingga Universitas Negeri Semarang melalui Elizabeth. Gambar rute Bus Rapid Transit (BRT) Semarang dapat dilihat pada gambar 1.1.

\section{Gambar 1.1}

Rute jalur BRT Trans Semarang Koridor I, II, III, IV,V dan VI

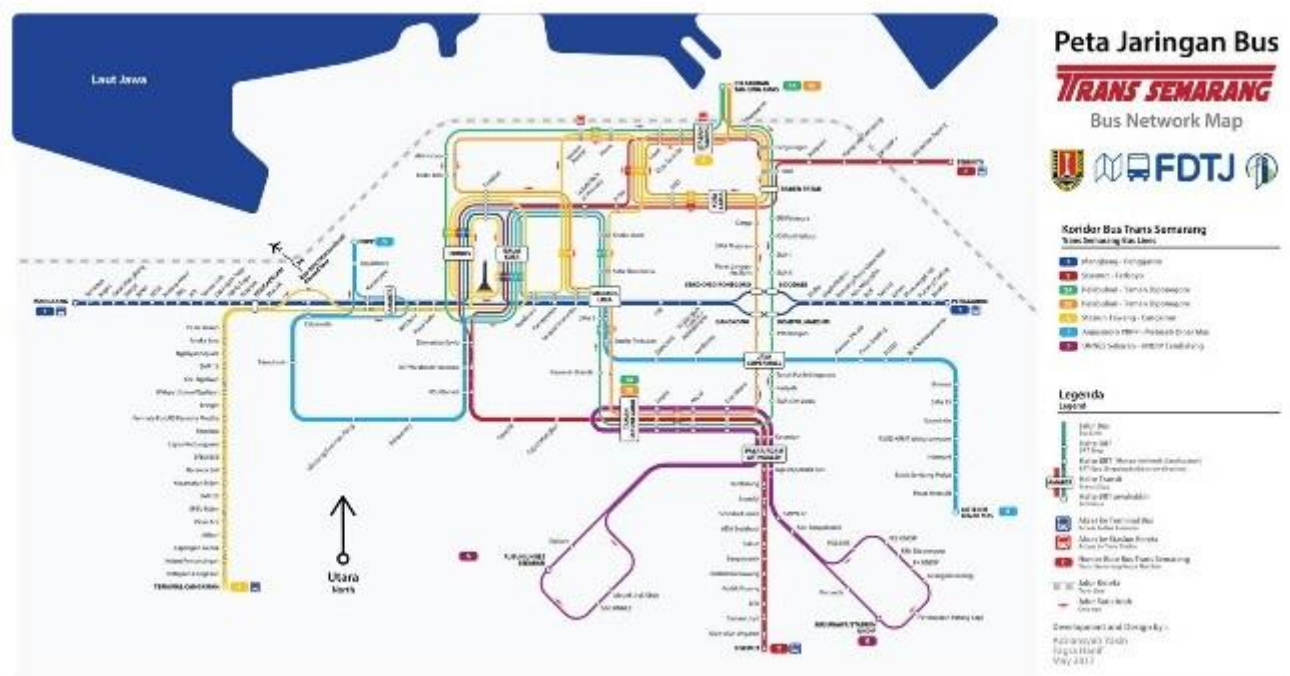

Sumber : BLU UPTD Terminal Mangkang BRT Trans Semarang.

Diharapkan dengan adanya Bus Rapid Transit (BRT) ini mampu menangani permasalahan seperti kepadatan dan kemacetan di Semarang dapat berkurang. Bus Rapid Transit Semarang bukan hanya menyediakan alat transportasi yang cepat, aman, nyaman dan murah tapi juga memberikan kualitas pelayanan yang baik kepada penggunanya. Mempertahankan dan meningkatkan kepuasan pelanggan, perusahaan harus terus meningkatkan kualitas pelayanan jasa agar tetap unggul, maka perusahaan dituntut untuk melakukan perbaikan dan perubahan yang lebih baik lagi. Salah satu cara untuk mengetahui persepsi kualitas pelayanan jasa 
perusahaan saat ini yaitu melalui informasi dari pelanggan mengenai kepuasan terhadap pelayanan yang diberikan Bus Trans Semarang, namun dalam kenyataannya yang menjadi permasalahan dari Bus Trans Semarang adalah tingkat kritik dari konsumen relatif tinggi yang ditujukan pada Bus Trans Semarang. Banyaknya keluhan pelanggan Bus Trans Semarang bisa dilihat pada tabel 1.1

TABEL 1.1

KELUHAN PELANGGAN BUS RAPID TRANSIT (BRT) SEMARANG

TAHUN 2017-2018

TABEL REKAPITULASI KELUHAN \& SARAN TERKAIT BRT TRANS SEMARANG TAHUN 2017-2018

\begin{tabular}{|l|l|l|l|l|l|l|l|}
\hline & $\begin{array}{l}\text { KORID } \\
\text { OR 1 }\end{array}$ & $\begin{array}{l}\text { KORID } \\
\text { OR 2 }\end{array}$ & $\begin{array}{l}\text { KORID } \\
\text { OR 3 }\end{array}$ & $\begin{array}{l}\text { KORID } \\
\text { OR 4 }\end{array}$ & $\begin{array}{l}\text { KORID } \\
\text { OR 5 }\end{array}$ & $\begin{array}{l}\text { KORID } \\
\text { OR 6 }\end{array}$ & TOTAL \\
\hline Agustus & 17 & 10 & 5 & 12 & 9 & 3 & 56 \\
\hline September & 10 & 26 & 7 & 5 & 12 & 9 & 69 \\
\hline Oktober & 11 & 19 & 9 & 13 & 13 & 7 & 72 \\
\hline November & 9 & 13 & 8 & 10 & 20 & 3 & 63 \\
\hline Desember & 12 & 9 & 4 & 8 & 6 & 10 & 49 \\
\hline Januari & 15 & 8 & 4 & 18 & 13 & 4 & 62 \\
\hline Februari & 12 & 26 & 8 & 9 & 10 & 6 & 71 \\
\hline Maret & 9 & 22 & 7 & 13 & 7 & 3 & 61 \\
\hline April & 7 & 12 & 3 & 7 & 11 & 4 & 44 \\
\hline Mei & 12 & 11 & 9 & 10 & 9 & 2 & 53 \\
\hline Juni & 23 & 8 & 3 & 9 & 10 & 6 & 59 \\
\hline
\end{tabular}




\begin{tabular}{|l|l|l|l|l|l|l|l|} 
Juli & 16 & 20 & 11 & 4 & 8 & 7 & 66 \\
\hline Total & 153 & 184 & 78 & 118 & 128 & 64 & 725 \\
\hline
\end{tabular}

Sumber : BLU UPTD Terminal Mangkang BRT Trans Semarang

TABEL 1.2

TESTIMONIAL KELUHAN PENUMPANG

BUS RAPID TRANSIT (BRT) SEMARANG TAHUN 2018

\begin{tabular}{|c|c|c|}
\hline PELAPOR & $\begin{array}{l}\text { MEDIA } \\
\text { PENGADUAN }\end{array}$ & SUBSTANSI PENGADUAN \\
\hline \multirow[t]{2}{*}{ Ismanto } & Lapor Hendi & $\begin{array}{l}\text { Kondisi Shelter tidak layak di depan } \\
\text { Mataram Sakti Motor Pedurungan }\end{array}$ \\
\hline & Lapor Hendi & Pelayanan petugas koridor 1 kurang ramah \\
\hline \multirow[t]{2}{*}{089667709689} & WhatsApp & $\begin{array}{l}\text { Rute BRT koridor } 2 \text { sisemut terboyo tidak } \\
\text { efisien dan menambah kemacetan di } \\
\text { Thamrin }\end{array}$ \\
\hline & Lapor Hendi & Driver koridor 1.011 ugal-ugalan \\
\hline \multirow[t]{2}{*}{ @indrakurnia_kjy } & Instagram & Shelter terminal penggaron terlihat kusam \\
\hline & Telephone No Aduan & Driver koridor 1.014 ugal-ugalan \\
\hline Heri Santoso & Facebook & $\begin{array}{l}\text { Petugasbersikap tidak ramah saaat memberi } \\
\text { arahan untuk pengguna jasa }\end{array}$ \\
\hline \multirow[t]{2}{*}{081325598740} & WhatsApp & $\begin{array}{l}\text { Rute BRT koridor } 2 \text { sisemut terboyo tidak } \\
\text { efisien dan menambah kemacetan di } \\
\text { Thamrin }\end{array}$ \\
\hline & Lapor Hendi & $\begin{array}{llll}\text { Driver armada } 1.012 \text { menyalip } & \text { dan } \\
\text { menyerobot jalur pengguana jalan } & \text { dan } \\
\text { hamir terserempet } & & & \\
\end{array}$ \\
\hline Laely Ramadhani & Facebook & $\begin{array}{l}\text { Armada tidak berhenti di shelter RS.Tugu } \\
\text { arah Penggaron }\end{array}$ \\
\hline Princess Arum & Facebook & pta 1.017 tiak bersikap ramah \\
\hline Yefta Kurniawan & Facebook & Driver 1.004 ugal-ugalan \\
\hline \multirow[t]{2}{*}{ zufar_official } & Instagram & Shelter damri atapnya hilang \\
\hline & Lapor Hendi & Shelter gajahmungkur rusak berlubang \\
\hline
\end{tabular}




\begin{tabular}{|l|l|l|} 
Candrakenny & Instagram & $\begin{array}{l}\text { kebersihan Armada dari sisemut jam 05.51 } \\
\text { bau rokok }\end{array}$ \\
\hline 082221385340 & SMS No Aduan & $\begin{array}{l}\text { Driver 2 sgo 2 terobos traficlight ADA } \\
\text { Srondol }\end{array}$ \\
\hline septiannugroho_ & Lapor Hendi & Kondisi Shelter sukun tidak layak \\
\hline @truli_wendev & Twitter & $\begin{array}{l}\text { Armada 2.027 kursi tidak layak } \\
\text { Kondisi shelter ungaran setiabudi, } \\
\text { layak }\end{array}$ \\
\hline komunitas_ssc & Lapor Hendi & Driver armada 3.009 ugal-ugalan \\
\hline Triyanto & Instagram & Armada 3.002 kumuh, ac mati, pintu rusak \\
\hline
\end{tabular}

Sumber : BLU UPTD Terminal Mangkang BRT Trans Semarang

Banyaknya tingkat kritik keluhan dari konsumen yang ditujukan pada Bus Trans Semarang sehingga membuat Bus (BRT) Trans Semarang perlu menurunkan keluhan melalui peningkatan pelayanan inti (core service quality) agar pelanggan semakin senang dengan layanan Bus Trans Semarang, oleh karena itu perlu penanganan terhadap keluhan dengan meningkatkan kepuasan pelanggan melalui pelayanan inti (core service quality) dan pendukungnya atau pelayanan periferal (peripheral service quality).

\section{Rumusan Masalah}

Berdasarkan uraian pada latar belakang masalah bahwa masih banyak keluhan yang dirasakan oleh pelanggan atas pelayanan Bus BRT Trans Semarang. hal ini menunjukkan bahwa kepuasan pelanggan Bus Trans Semarang tersebut menurun. Hal tersebut dapat dilihat dari keluhan-keluhan dari masyarakat. Menurut Agustin, dkk (2016) menyatakan bahwa kualitas layanan inti berpengaruh positif terhadap kepuasan pelanggan sedangkan Firmansyah, dkk (2016) menyatakan bahwa kualitas layanan peripheral berpengaruh positif terhadap kepuasan pelanggan.

Bus Trans Semarang perlu melakukan kajian mendalam mengenai pelayanan inti (core service quality) dan pelayanan periferal (peripheral service quality) dalam mendukung tingkat kepuasan pelanggan, dimana dengan pelanggan yang puas mampu meningkatkan minat Word of mouth. Berdasarkan rendahnya kepuasan konsumen yang terjadi pada Bus BRT Trans Semarang, 
maka rumusan masalah penelitian yaitu bagaimana meningkatkan kepuasan konsumen sehingga dapat meningkatkan minat word of mouth pada konsumen yang menggunakan Bus BRT Trans Semarang. Dengan demikian pertanyaan penelitiannya sebagai berikut:

1. Bagaimana pengaruh kualitas pelayanan inti terhadap kepuasan konsumen?

2. Bagaimana pengaruh kualitas pelayanan inti terhadap Word Of Mouth?

3. Bagaimana pengaruh kualitas pelayanan periferal terhadap kepuasan konsumen?

4. Bagaimana pengaruh kualitas pelayanan periferal terhadap Word Of Mouth?

5. Bagaimana pengaruh kepuasan konsumen terhadap Word Of Mouth ?

\section{TINJAUAN PUSTAKA}

\section{Kualitas Pelayanan Inti dan Kepuasan Konsumen}

Kotler dan Keller (2007:56) menyatakan bahwa kualitas pelayanan harus dimulai dari kebutuhan pelanggan dan berakhir pada persepsi pelanggan, dimana persepsi pelanggan terhadap kualitas pelayanan merupakan penilaian menyeluruh atas keunggulan suatu pelayanan. Menurut Parasuraman (1998) dalam Tjiptono (2005) bahwa terdapat lima dimensi kualitas layanan yaitu, tangible, realibility, responsiveness, assurance, emphaty.

Hal ini sesuai dengan penelitian yang dilakukan oleh Hilman faza (2016) dan Emel Yildiz (2017) yang menyatakan bahwa variabel kualitas pelayanan inti berpengaruh positif dan signifikan terhadap kepuasan konsumen. Dari penelitian yang telah dilakukan sebelumnya dan teori yang telah dijelaskan diatas, maka dalam penelitian ini diusulkan hipotesis sebagai berikut:

H1= Kualitas Pelayanan Inti diduga berpengaruh terhadap kepuasan konsumen 


\section{Kualitas Pelayanan Inti dan Word Of Mouth}

Menurut Kotler dan Keller (2009:512) mendefinisikan word of Mouth adalah kegiatan pemasaran melalui perantara orang ke orang disekitarnya baik secara lisan, tulisan, maupun alat komunikasi elektronik yang berhubungan dengan pengalaman pembelian jasa atau pengalaman menggunakan produk atau jasa. Word of mouth memiliki kekuatan besar yang berdmpak pada perilaku pembelian konsumen. Rekomendasi dari teman yang sudah dipercaya, asosiasi, dan konsumen lain berpotensi untuk lebih dipercaya dibanding dari sumber komersil, seperti iklan dan sales people.

Menurut Yildiz (2017) menyatakan bahwa kualitas pelayanan merupakan indikator penting bagi perusahaan untuk bersaing, oleh karena itu mereka harus menawarkan konsumen layanan yang berkualitas tinggi karena pelanggan yang puas akan mengacu pada perilaku konsumen memberi tahu orang lain tentang pengalaman mereka dengan produk dan jasa. Hal ini sesuai dengan penelitian yang dilakukan oleh Hilman faza (2016) dan Firmansyah dan khasanah (2016) yang menyatakan bahwa variabel kualitas pelayanan inti berpengaruh positif dan signifikan terhadap word of mouth. Dari penelitian yang telah dilakukan sebelumnya dan teori yang telah dijelaskan diatas, maka dalam penelitian ini diusulkan hipotesis sebagai berikut:

H2= Kualitas Pelayanan Inti diduga berpengaruh terhadap Word Of Mouth

\section{Kualitas Pelayanan Periferal dan Kepuasan Konsumen}

Tjiptono dan Chandra (2006:258) menyatakan Kualitas pelayanan (service quality) dapat diketahui dengan cara membandingkan persepsi para konsumen atas pelayanan yang nyata-nyata mereka terima atau peroleh dengan pelayanan yang sesungguhnya mereka harapkan terhadap atribut-atribut pelayanan suatu perusahaan. Jika jasa yang diterima atau dirasakan (perceived service) sesuai dengan yang diharapkan, maka kualitas pelayanan dipersepsikan baik dan memuaskan, jika jasa yang diterima melampaui harapan konsumen, maka kualitas pelayanan dipersepsikan sangat baik dan berkualitas. 
Hal ini sesuai dengan penelitian yang dilakukan oleh Hilman faza (2016) dan Firmansyah dan khasanah (2016) yang menyatakan bahwa variabel kualitas pelayanan periferal berpengaruh positif dan signifikan terhadap kepuasan konsumen. Dari penelitian yang telah dilakukan sebelumnya dan teori yang telah dijelaskan diatas, maka dalam penelitian ini diusulkan hipotesis sebagai berikut: H3 = Kualitas Pelayanan Periferal diduga berpengaruh terhadap Kepuasan Konsumen

\section{Kualitas Pelayanan Periferal dan Word Of Mouth}

Menurut Sam liu, dkk (2016) berpendapat bahwa konsumen akan menilai kualitas tinggi jika nilai yang dirasakan memenuhi harapan mereka selain itu seiring meningkatnya kualitas layanan maka akan ada kemauan untuk merekomendasikan kepada orang lain. pelayanan dipersepsikan sangat baik dan berkualitas.

Hal ini sesuai dengan penelitian yang dilakukan oleh Hilman faza (2016) dan Firmansyah (2016) yang menyatakan bahwa variabel kualitas pelayanan periferal berpengaruh positif dan signifikan terhadap word of mouth. Dari penelitian yang telah dilakukan sebelumnya dan teori yang telah dijelaskan diatas, maka dalam penelitian ini diusulkan hipotesis sebagai berikut:

H4 = Kualitas Pelayanan Periferal diduga berpengaruh terhadap Word of Mouth

\section{Kepuasan Konsumen dan Word Of Mouth}

Menurut Kotler dan Amstrong $(2008$;16) Kepuasan Konsumen merupakan persepsi konsumen terhadap kinerja anggapan produk relatif terhadap ekspektasi pembeli. Jika kinerja produk tidak memenuhi ekspektasi, pelanggan kecewa. Jika kinerja produk sesuai dengan ekspektasi, pelanggan puas. Jika kinerja melebihi ekspektasi, pelanggan sangat puas.

Menurut Pappachan (2016) menyatakan bahwa kepuasan konsumen berpengaruh positif terhadap word of mouth, salah satu keunggulan kompetitif yang dapat diciptakan perusahaan adalah memfokuskan bisnisnya pada kepuasan 
pelanggan, apabila pelayanan yang diterima atau dirasakan sesuai dengan yang diharapkan, maka kualitas pelayanan dipersepsikan baik dan memuaskan, sehingga melalui kepuasan itu konsumen akan melakukan pembelian jasa atau memutuskan untuk menggunakan jasa dan pada akhirnya akan merekomendasikan hal itu kepada orang lain. Hal ini sesuai dengan penelitian yang dilakukan oleh Hilman faza (2016) dan Firmansyah dan khasanah (2016) yang menyatakan bahwa variabel kepuasan konsumen berpengaruh positif dan signifikan terhadap word of mouth. Dari penelitian yang telah dilakukan sebelumnya dan teori yang telah dijelaskan diatas, maka dalam penelitian ini diusulkan hipotesis sebagai berikut:

H5 = Kepuasan Konsumen diduga berpengaruh terhadap Word of Mouth

\section{Kerangka Pemikiran Teoritis}

Berdasarkan latar belakang permasalahan diatas dan hipotesis yang telah di paparkan dari penelitian terdahulu, maka disusun suatu kerangka pemikiran dalam gambar 2.1.

Gambar 2.1

Model Kerangka Pemikiran Teoritis

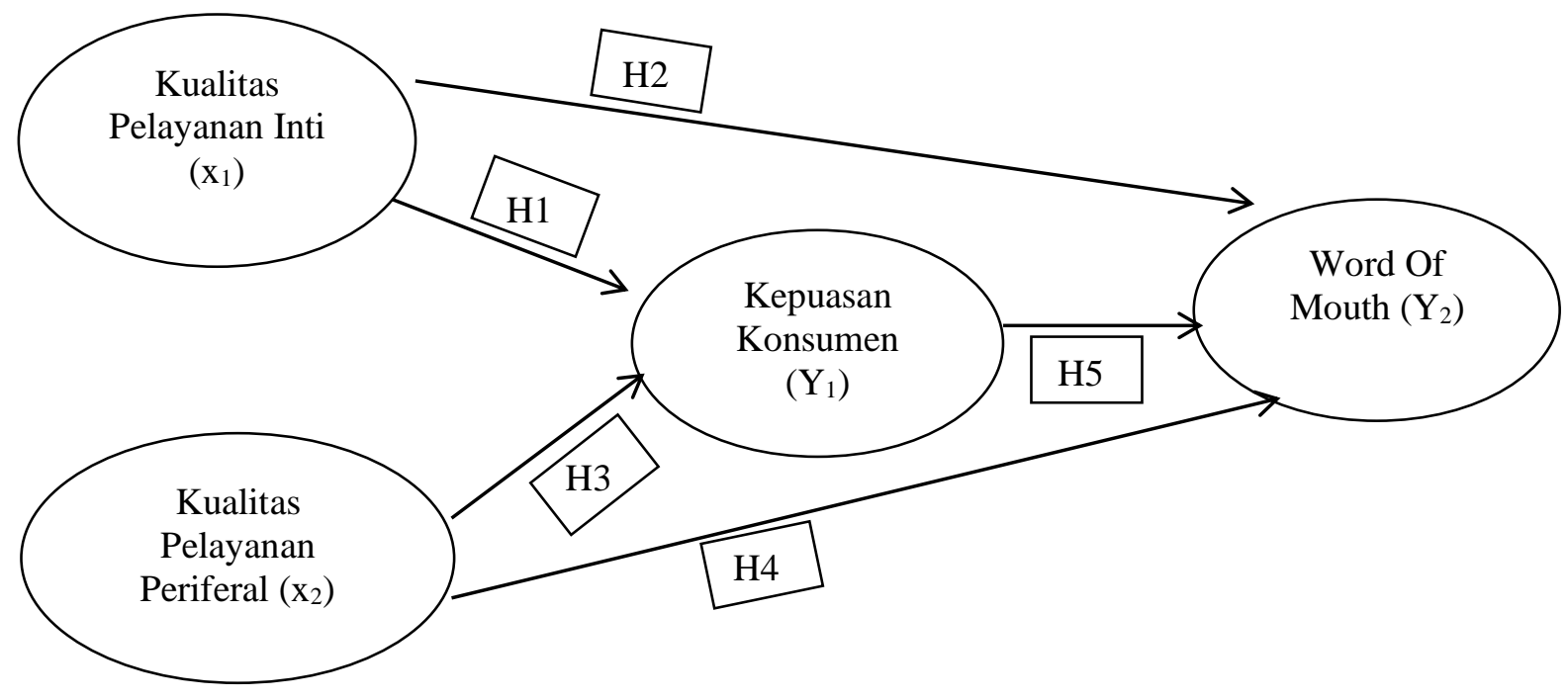

Sumber: konsep yang dikembangkan dalam penelitian 


\section{METODE PENELITIAN}

\section{Objek Penelitian dan Unit Sampel}

Menurut Arikunto (2012) Objek Penelitian adalah variabel penelitian, yaitu sesuatu yang merupakan inti dari problematika penelitian. Objek pada penelitian ini adalah Bus Trans Semarang merupakan perusahaan yang bergerak dibidang transportasi yang dikelola oleh Dinas Perhubungan kota Semarang. Unit sampel adalah suatu elemen atau sekelompok elemen yang menjadi dasar untuk dipilih sebagai sampel. Unit sampel yang digunakan adalah respon dari konsumen Bus Trans Semarang

\section{Populasi dan Penentuan Sampel}

Populasi dalam penelitian ini adalah seluruh penumpang BRT Trans Semarang. Jumlah penumpang BRT Semarang pada tahun 2017 sebanyak 9.125.472 pengguna. Total sampel yang digunakan sebagai responden dalam penelitian ini sebanyak 99 responden.

Teknik pengambilan sampel yang digunakan dalam penelitian ini menggunakan purposive sampling. Menurut Wijaya (2013:28) Purposive sampling adalah teknik penentuan sampel berdasarkan pertimbangan tertentu yang ditujukan kepada individu-individu yang memiliki kriteria. Sampel yang diambil diantaranya yang sudah menggunakan jasa Bus Trans Semarang lebih dari 2 kali dengan usia minimal 18 tahun, pendidikan minimal SLTA dan bekerja.

\section{Jenis dan Sumber Data}

Jenis data yang digunakan dalam penelitian ini adalah data primer dan sekunder. Penyusunan penelitian dibutuhkan data yang baik. Untuk mendapatkan data yang baik, teknik pengumpulan data yang digunakan antara lain : Kuisioner, Observasi dan Studi Pustaka. 


\section{Metode Analisis}

Dalam melakukan penelitian ini dilakukan analisis data dengan cara analisis kuantitatif. Dalam penelitian analisis data kuantitatif digunakan untuk mengolah data yang diperoleh dari jawaban kuesioner. Data primer adalah data langsung yang diperoleh dari responden tersebut kemudian diolah dan dilakukan pengujian hipotesis dengan menggunakan bantuan SPSS. Analisis yang digunakan adalah uji regresi linear berganda.

\section{PEMBAHASAN}

\section{Uji Validitas Data}

Hasil pengujian menunjukkan bahwa semua indikator yang digunakan untuk mengukur variabel-variabel yang digunakan dalam penelitian ini mempunyai koefisien korelasi dengan signifikansi lebih besar dari $r$ tabel sebesar 0,197 (Hasil uji dua arah). Dengan demikian semua indikator tersebut adalah valid.

\section{Uji Reliabilitas Data.}

Hasil uji reliabilitas tersebut menunjukkan bahwa semua variabel mempunyai koefisien Alpha yang cukup besar yaitu diatas 0,60 sehingga dapat dikatakan semua konsep pengukur masing-masing variabel dari kuesioner adalah reliabel sehingga untuk selanjutnya item-item pada masing-masing konsep variabel tersebut layak digunakan sebagai alat ukur.

\section{Uji Asumsi Klasik}

Jika suatu model masih terdapat adanya masalah asumsi klasik, maka akan dilakukan langkah revisi model ataupun penyembuhan untuk menghilangkan masalah tersebut. Pengujian asumsi klasik akan dilakukan berikut ini. 


\section{Uji Normalitas}

Hasil pengujian model 1 dan 2 menunjukkan nilai Uji Kolmogorov Smirnov sebesar 0.611 dan 0.958 lebih besar dari 0,05 maka data terdistribusi normal.

\section{Pengujian Multikolonieritas}

Hasil pengujian menunjukkan bahwa nilai VIF dari semua variabel pada pengujian model satu dan dua memiliki nilai yang lebih kecil dari 10. Hal ini berarti bahwa variabel-variabel penelitian tidak menunjukkan adanya gejala multikolonieritas dalam model regresi.

\section{Pengujian Heteroskedastisitas}

Hasil tampilan output SPSS dengan jelas menunjukkan semua model uji satu dan dua seluruh variabel independen mempunyai nilai sig $\geq 0,05$. Jadi tidak ada variabel independen yang signifikan secara statistik mempengaruhi variabel dependen nilai absolute dari residual. Hal ini terlihat dari nilai signifikan pada tiap-tiap variabel independen seluruhnya diatas 0,05. Jadi dapat disimpulkan model regresi tidak mengandung adanya heterokedastisitas.

\section{Analisis Regresi Linear Berganda}

Hasil persamaan regresi berganda memberikan pengertian bahwa kualitas pelayanan inti (X1), dan kualitas pelayanan periferal (X2) berpengaruh positif terhadap kepuasan konsumen $(\mathrm{Z})$

1. Nilai koefisien regresi kualitas pelayanan inti (b1) sebesar 0,479 dan bertanda positif (+) hal ini menunjukkan bahwa apabila kualitas pelayanan inti semakin meningkat maka kepuasan konsumen akan semakin meningkat

2. Nilai koefisien regresi kualitas pelayanan periferal (b2) sebesar 0,304 dan bertanda positif (+) hal ini menunjukkan bahwa apabila kualitas pelayanan periferal semakin meningkat maka kepuasan konsumen akan semakin meningkat 
Berdasarkan persamaan regresi tersebut dapat disimpulkan bahwa variabel kualitas pelayanan inti (X1) sangat dominan berpengaruh terhadap kepuasan konsumen (Z), kemudian diikuti variabel kualitas pelayanan periferal (X2).

Hasil persamaan regresi berganda diatas memberikan pengertian bahwa kualitas pelayanan inti (X1), kualitas pelayanan periferal (X2) berpengaruh positif dan kepuasan konsumen $(\mathrm{Z})$ berpengaruh positif terhadap word of mouth $(\mathrm{Y})$

1. Nilai koefisien regresi kualitas pelayanan inti (b3) sebesar 0,225 dan bertanda positif (+) hal ini menunjukkan bahwa apabila kualitas pelayanan inti semakin meningkat maka word of mouth akan semakin meningkat.

2. Nilai koefisien regresi kualitas pelayanan periferal (b4) sebesar 0,179 dan bertanda positif (+) hal ini menunjukkan bahwa apabila kualitas pelayanan periferal semakin meningkat maka word of moth akan semakin meningkat.

3. Nilai koefisien regresi kepuasan konsumen (b5) sebesar 0,435 dan bertanda positif (+) hal ini menunjukkan bahwa apabila kepuasan konsumen semakin meningkat maka word of moth akan semakin meningkat.

Berdasarkan persamaan regresi tersebut di atas dapat disimpulkan bahwa variabel kepuasan konsumen $(\mathrm{Z})$ sangat dominan berpengaruh terhadap word of mouth (Y), kemudian diikuti variabel kualitas pelayanan inti (X1) dan kualitas pelayanan periferal (X2).

\section{Koefisien Deteterminasi $\left(\mathbf{R}^{2}\right)$}

Uji $\mathrm{R}^{2}$ atau uji determinasi merupakan suatu ukuran yang penting dalam regresi, karena dapat menginformasikan baik atau tidaknya model regresi yang terestimasi, atau dengan kata lain angka tersebut dapat mengukur seberapa dekatkah garis regresi yang terestimasi dengan data sesungguhnya. Nilai koefisien determinasi $\left(\mathrm{R}^{2}\right)$ ini mencerminkan seberapa besar variasi dari variabel terikat $\mathrm{Y}$ dapat diterangkan oleh variabel bebas $\mathrm{X}$. Bila nilai koefisien determinasi sama dengan $0\left(\mathrm{R}^{2}=0\right)$ artinya variasi dari $\mathrm{Y}$ 
tidak dapat diterangkan oleh $\mathrm{X}$ sama sekali. Sementara bila $\left(\mathrm{R}^{2}=1\right)$ artinya variasi dari Y secara keseluruhan dapat diterangkan oleh X. Dengan kata lain bila $\left(\mathrm{R}^{2}=1\right)$, maka semua titik pengamatan berada tepat pada garis regresi. Dengan demikian baik atau buruknya suatu persamaan regresi ditentukan oleh $\mathrm{R}^{2}$ nya yang mempunyai nilai antara nol dan satu (Ghozali,2012)

Nilai koefisien determinasi (adjusted R Square) adalah sebesar 0,414 atau 41,4\% berarti variasi perubahan kepuasan konsumen dipengaruhi variabel kualitas pelayanan inti dan kualitas pelayanan periferal sebesar $41,4 \%$ dan sisanya $58,6 \%$ dipengaruhi oleh faktor-faktor lain.

Nilai koefisien determinasi (adjusted R Square) adalah sebesar 0,473 atau $47,3 \%$ berarti variasi perubahan word of mouth dipengaruhi variabel kualitas pelayanan inti, kualitas pelayanan periferal, dan kepuasan konsumen sebesar 47,3\% dan sisanya 52,7\% dipengaruhi oleh faktor-faktor lain.

\section{Koefisien Determinasi Total}

Nilai determinasi pada model pertama $\left(\mathrm{R} 1^{2}\right)$ yaitu sebesar 0,414 dan nilai determinasi pada model kedua $\left(\mathrm{R} 2^{2}\right)$ yaaitu sebesar 0,473

$\mathrm{P}^{2} \mathrm{e} 1=1-0,414=0,586$

$\mathrm{P}^{2} \mathrm{e}_{2}=1-0,473=0,527$

Sehingga diperoleh koefisien determinasi total adalah sebagai berikut:

$\mathrm{R}^{2} \mathrm{~m}=1-(\mathrm{Pe} 1)^{2}(\mathrm{Pe} 2)^{2}$

$\mathrm{R}^{2} \mathrm{~m}=1-(0,586)^{2}(0,527)^{2}$

$\mathrm{R}^{2} \mathrm{~m}=1-(0,343) .(0,277)$

$\mathrm{R}^{2} \mathrm{~m}=1-0,095=0,905$

Dari rumus tersebut nilai $\mathrm{R}^{2}$ sebesar $90,5 \%$ yang artinya variabel word of mouth dapat dijelaskan oleh variabel kualitas pelayanan inti, kualitas pelayanan periferal, dan kepuasan konsumen sedangkan sisanya sebesar 9,5\% dipengaruhi oleh faktor-faktor lain yang tidak dimasukkan kedalam model atau yang tidak diteliti dalam penelitian ini. 


\section{Uji intervening (Sobel test)}

Sobel test merupakan uji untuk mengetahui apakah hubungan yang melalui sebuah variabel mediasi secara signifikan mampu sebagai mediator dalam hubungan tersebut. Hasil perhitungan dengan uji z sebagai berikut:

a : $\quad$ koefisien regresi variabel independen terhadap variabel mediasi.

B : $\quad$ koefisien regresi variabel mediasi terhadap variabel Dependen.

$S E_{a}^{2} \quad: \quad$ standar error of estimation dari pengaruh variabel Independen terhadap variabel mediasi.

$S E_{b}^{2} \quad$ : Standar error of estimation dari pengaruh variabel mediasi teradap variabel Independen

$$
Z=\frac{a b}{\sqrt{\left(b^{2} S E_{a}^{2}\right)+\left(a^{2} S E_{b}^{2}\right)}}
$$

Dari hasil perhitungan sobel test di atas mendapatkan :

1.

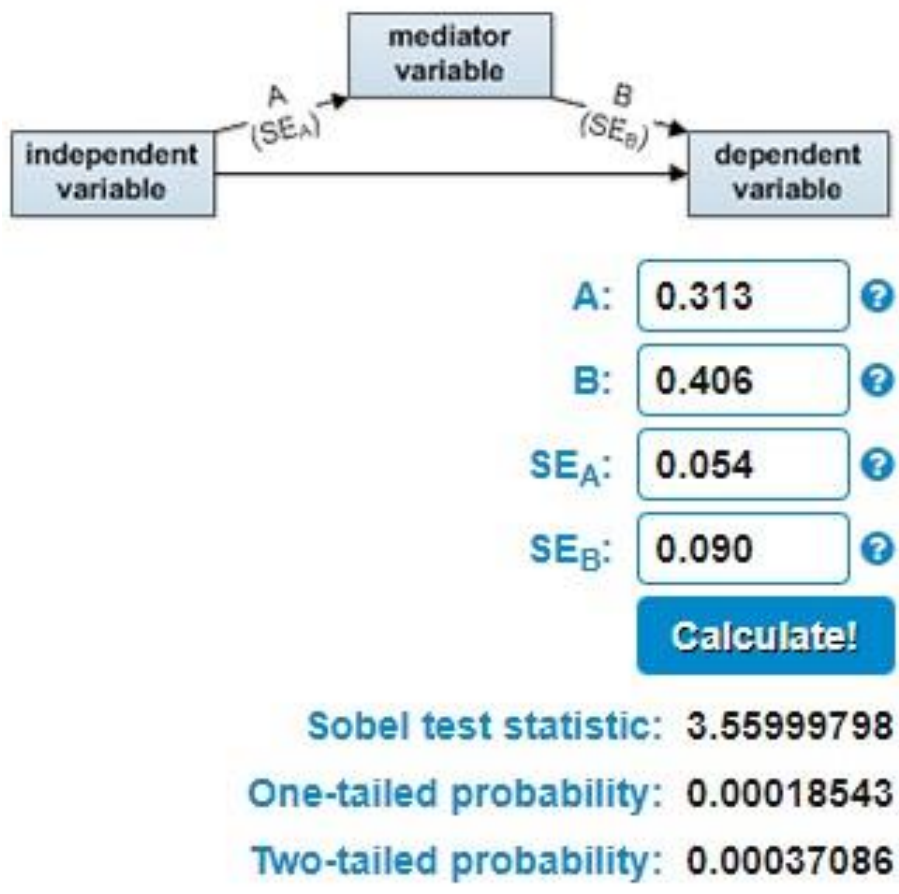


Nilai z pada variabel kualitas pelayanan inti sebesar 3,559 dan karena nilai z yang diperoleh sebesar 3,559>1,96 ( $\mathrm{t}$ tabel pada taraf $5 \%$ yaitu 1,96) maka membuktikan bahwa kepuasan konsumen mampu memediasi hubungan pengaruh kualitas pelayanan inti terhadap word of mouth

2 .

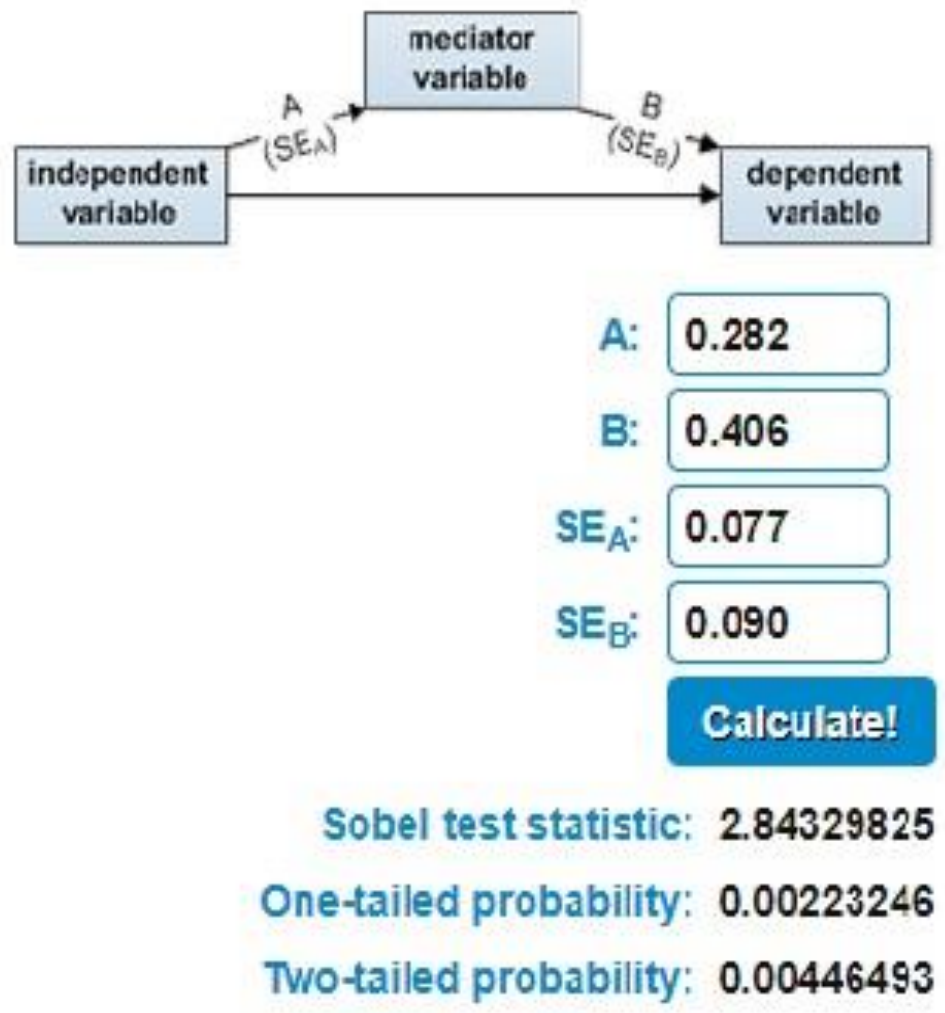

Nilai z pada variabel kualitas pelayanan periferal sebesar 2,843 dan karena nilai z yang diperoleh sebesar 2,843>1,96 (t tabel pada taraf 5\% yaitu 1,96) maka membuktikan bahwa kepuasan konsumen mampu memediasi hubungan pengaruh kualitas pelayanan periferal terhadap word of mouth.

\section{Pembahasan}

\section{Pengaruh kualitas pelayanan inti Terhadap Kepuasan konsumen.}

Kualitas pelayanan terhadap kepuasan konsumen sangat erat kaintannya. Konsumen pasti ingin mendapatkan pelayanan yang memuaskan dan sesuai keinginan mereka. Produk yang berkualitas yaitu produk yang sesuai dengan kebutuhan dan keinginan konsumen. Menurut Yildiz (2017) menyatakan bahwa kualitas pelayanan merupakan indikator penting bagi perusahaan untuk bersaing, oleh karena itu mereka harus menawarkan konsumen layanan yang berkualitas 
tinggi karena pelanggan yang puas akan mengacu pada perilaku konsumen memberi tahu orang lain tentang pengalaman mereka dengan produk dan jasa Hasil pengujian regresi menunjukkan kualitas pelayanan inti memiliki pengaruh yang positif dan nilai signifikansi hasil sebesar 0.000 lebih kecil dari tingkat signifikansi sebesar 0,05 yang artinya bahwa kualitas pelayanan inti mempunyai pengaruh positif dan signifikan terhadap kepuasan konsumen. Penelitian ini mendukung hasil penelitian dari Hilman faza (2016) dan Firmansyah (2016) berpengaruh positif dan signifikan terhadap kepuasan konsumen

\section{Pengaruh Kualitas Pelayanan periferal Terhadap Kepuasan konsumen.}

Tjiptono dan Chandra (2006:258) menyatakan bahwa kualitas pelayanan adalah fungsi harapan pelanggan pada pra pembelian, pada proses penyediaan kualitas yang diterima dan pada kualitas output yang diterima. Jika jasa yang diterima atau dirasakan (perceived service) sesuai dengan yang diharapkan, maka kualitas pelayanan dipersepsikan baik dan memuaskan, jika jasa yang diterima melampaui harapan konsumen, maka kualitas pelayanan dipersepsikan sangat baik dan berkualitas.

Hasil pengujian regresi menunjukkan variabel kualitas produk memiliki pengaruh yang positif dan nilai signifikansi hasil sebesar 0.000 lebih kecil dari tingkat signifikansi sebesar 0,05 yang artinya bahwa kualitas produk mempunyai pengaruh positif dan signifikan terhadap keputusan pembelian. Penelitian ini mendukung hasil penelitian dari Hilman faza (2016) dan Firmansyah (2016) yang menyatakan kualitas pelayanan periferal berpengaruh positif dan signifikan terhadap kepuasan konsumen.

\section{Pengaruh kualitas pelayanan inti Terhadap word of mouth.}

Menurut Sam liu, dkk (2016) berpendapat bahwa konsumen akan menilai kualitas tinggi jika nilai yang dirasakan memenuhi harapan mereka selain itu seiring meningkatnya kualitas layanan maka akan ada kemauan untuk merekomendasikan kepada orang lain. pelayanan dipersepsikan sangat baik dan berkualitas. Hasil pengujian regresi menunjukkan variabel kualitas pelayanan inti memiliki pengaruh yang positif dan nilai signifikansi hasil sebesar 0.015 lebih 
kecil dari tingkat signifikansi sebesar 0,05 yang artinya bahwa kualitas pelayanan inti mempunyai pengaruh positif dan signifikan terhadap word of mouth dan nilai z pada variabel kualitas pelayanan inti sebesar 3,559 dan karena nilai z yang diperoleh sebesar 3,559 >1,96 ( $\mathrm{t}$ tabel pada taraf 5\% yaitu 1,96) maka membuktikan bahwa kualitas pelayanan inti mampu memediasi hubungan pengaruh kepuasan konsumen terhadap word of mouth.

\section{Pengaruh Kualitas pelayanan periferal terhadap word of mouth}

Kualitas pelayanan (service quality) dapat diketahui dengan cara membandingkan persepsi para konsumen atas pelayanan yang nyata-nyata mereka terima atau peroleh dengan pelayanan yang sesungguhnya mereka harapkan terhadap atribut-atribut pelayanan suatu perusahaan. Jika jasa yang diterima atau dirasakan (perceived service) sesuai dengan yang diharapkan, maka kualitas pelayanan dipersepsikan baik dan memuaskan, jika jasa yang diterima melampaui harapan konsumen, maka kualitas pelayanan dipersepsikan sangat baik dan berkualitas Tjiptono dan Chandra (2006:258).

Hasil pengujian regresi menunjukkan variabel kualitas pelayanan periferal memiliki pengaruh yang positif dan nilai signifikansi hasil sebesar 0.035 lebih kecil dari tingkat signifikansi sebesar 0,05 yang artinya bahwa kualitas pelayanan periferal mempunyai pengaruh positif dan signifikan terhadap word of mouth dan nilai z pada variabel kualitas pelayanan periferal sebesar 2,843 dan karena nilai z yang diperoleh sebesar 2,843 >1,96 ( t tabel pada taraf 5\% yaitu 1,96) maka membuktikan bahwa kualitas pelayanan periferal mampu memediasi hubungan pengaruh kepuasan konsumen terhadap word of mouth.

\section{SIMPULAN DAN SARAN}

\section{Simpulan.}

Latar belakang permasalahan yang diangkat dalam penelitian ini dimana Fenomena dilapangan Bus Trans Semarang menerima keluhan dari konsumen pengguna Bus Trans Semarang yang relatif tinggi adapun keluhan tersebut bisa 
dilihat pada 3 bulan terakhir mengalami kenaikan pada keluhan atau kritikan yang dirasakan oleh konsumen pengguna Bus Trans Semarang. Berdasarkan penelitian yang dilakukan maka dapat dibuat kesimpulan sebagai berikut:

1. Pengujian hipotesis yang dilakukan membuktikan bahwa terdapat pengaruh positif dan signifikan antara kualitas pelayanan inti terhadap kepuasan konsumen.

2. Pengujian hipotesis yang dilakukan membuktikan bahwa terdapat pengaruh positif dan signifikan antara kualitas pelayanan periferal terhadap kepuasan konsumen.

3. Pengujian hipotesis yang dilakukan membuktikan bahwa terdapat pengaruh positif dan signifikan antara kualitas pelayanan inti terhadap word of mouth.

4. Pengujian hipotesis yang dilakukan membuktikan bahwa terdapat pengaruh positif dan signifikan antara kualitas pelayanan periferal terhadap word of mouth

5. Pengujian hipotesis yang dilakukan membuktikan bahwa terdapat pengaruh positif dan signifikan antara kepuasan konsumen terhadap word of mouth.

\section{Saran.}

Berdasarkan hasil penelitian yaitu kualitas pelayanan inti dan kualitas pelayanan periferal ternyata secara positif dan signifikan berpengaruh dalam meningkatkan kepuasan konsumen dan word of mouth. Dengan demikian hasil penelitian ini telah menunjukkan bahwa variabel-variabel tersebut perlu lebih diperhatikan oleh manajemen Bus Trans Semarang yang meliputi :

1. Berdasarkan hasil penelitian pada variabel kualitas pelayanan inti diketahui terdapat indikator dengan nilai yang rendah pada indikator no.1 yaitu masih ada sebagian konsumen yang kurang nyaman saat menggunakan Bus Trans Semarang karena masih dianggap kondisi bus kurang bersih. Sebaiknya yang dilakukan Bus Trans Semarang yaitu memperhatikan kebersihan pada armada yang ada di setiap koridor dan 
mengevaluasi sumber daya manusia secara terus menerus agar mampu memberikan yang terbaik bagi pengguna Bus Trans Semarang.

2. Berdasarkan hasil penelitian pada variabel kualitas pelayanan periferal diketahui terdapat indikator dengan nilai yang rendah pada indikator no.2 yaitu masih ada sebagian konsumen yang merasa halte atau shelter kurang memberi kenyamanan karena banyak halte yang kondisinya kotor dan kurang terawat sehingga membuat konsumen merasa kurang begitu nyaman saat menunggu kedatangan Bus Trans Semarang. Sebaiknya yang dilakukan Bus Trans Semarang yaitu selalu memperhatikan kebersihan halte dan juga melakukan perawatan terhadap halte dengan melakukan kontroling yang ada pada setiap koridor, disarankan juga pada setiap halte diberi tempat sampah agar konsumen tidak membuang sampah sembarangan.

3. Berdasarkan hasil penelitian pada variabel kepuasan konsumen diketahui terdapat indikator dengan nilai yang rendah pada indikator no.2 yaitu masih ada sebagian konsumen yang merasa bahwa masih belum terpenuhinya harapan konsumen terhadap pelayanan Bus Trans Semarang. Sebaiknya Bus Trans Semarang perlu meningkatkan mutu dan kualitas pelayanan karena kepuasan yang dirasakan oleh konsumen sangatlah penting dalam meningkatkan permintaan jasa dan agar konsumen beralih untuk menggunakan jasa Bus Trans Semarang sehingga mampu mengurangi kemacetan yang ada di kota Semarang.

\section{Keterbatasan Penelitian}

Dalam melakukan penelitian masih terdapat berbagai kelemahan dan kekurangan, walaupun penulis telah berupaya maksimal mungkin dengan berbagai usaha untuk membuat hasil penelitian ini bisa menjadi sempurna. penulis menyadari bahwa keterbatasan penulisan ini antara lain :

1. Respon yang rendah dari responden, ditandai dengan banyaknya responden yang tidak langsung mengisi kuesioner, sehingga membutuhkan waktu yang lama 
2. Penelitian ini hanya menerapkan metode survei melalui kuesioner tertutup sehingga kurang tajam dalam menggali harapan dan apa yang diinginkan responden sebenarnya. Oleh karena itu kesimpulan yang diambil hanya berdasarkan pada data yang dikumpulkan melalui penggunaan instrumen secara tertulis tersebut.

3. hasil penelitian ini tidak dapat digeneralisasikan untuk kasus lain diluar objek penelitian.

\section{Agenda Penelitian Yang Akan Datang}

Penelitian mengenai analisis faktor-faktor yang mempengaruhi kepuasan konsumen dan word of mouth masih mungkin untuk dikembangkan lebih lanjut pada penelitian mendatang. Hal-hal yang mungkin dapat dikembangkan yaitu dengan mempertimbangkan untuk menambahkan variabel dan lain sebagainya. Selain itu dalam penelitian mendatang perlu memperluas objek penelitian.

\section{DAFTAR PUSTAKA}

Alma, Buchari. 2007. Manajemen Pemasaran dan Pemasaran Jasa. Alfabeta : Bandung.

Amstrong, Gary and Philip Kotler. 2002. Dasar-dasar Pemasaran. Jilid 1. Alih Bahasa Alexander Sindoro dan Benyamin Molan. Prenhalindo : Jakarta.

Faza, Hilman dan Ibnu Widiyanto. 2016. "Studi Minat Mereferensikan Dalam Jasa Travel Umroh”. Jurnal Manajemen, Volume 5, No.1 : 1-15.

Firmansyah, Muhammad dan Imroatul Khasanah. 2016. "Pengaruh Kualitas Pelayanan Inti dan Kualitas Pelayanan Periferal Melalui Kepuasan Konsumen Pada Minat Merefrensikan (Studi Pada Bus Trans Jakarta Koridor I)". Jurnal Manajemen, Volume 5, No.4 : 1-11.

Ghozali, Imam. 2013. Aplikasi Analisis Multivariate dengan program IBM SPSS 21. Universitas Diponegoro: Semarang.

Hasan, Ali. 2010. Marketing dari Mulut ke Mulut. Media Pressindo : Yogyakarta.

Irawan, Handi. 2009. 10 Prinsip Kepuasan Pelanggan. Elek Media Komputindo : Jakarta.

Kotler, Philip dan Gary Amstrong. 2012. Prinsip-prinsip Pemasaran. Erlangga : Jakarta. 
Kotler, Philip dan Kevin Lane Keller. 2009. Manajemen Pemasaran Buku 1. Erlangga : Jakarta.

Pappachan, Joemon. 2016. "Moderation Effect Of Travel Context In The Linkage Among Employee Service Quality, Satisfaction, And Trust On Word Of Mouth Of Airline Passanger In India”. Journal of Marketing. Vol.1, No.1: 75-92.

Patilima, Hamid. 2011. Metode penelitian kualitatif. Alfabeta : Bandung.

Riduwan. 2008. Skala Pengukuran Variabel-variabel Penelitian. Alfabeta : Bandung.

Rombe, Febry Ferial. 2015. "Pengaruh Kualitas Pelayanan Inti dan Kualitas Pelayanan Periferal Terhadap Kepuasan Konsumen Pelanggan Serta Dampaknya Terhadap Minat Word of Mouth (Studi Pada Bengkel Body Repair Tri Tunggal di Kota Semarang)”. Semarang : Fakultas Ekonomika dan Bisnis Universitas Diponegoro.

Satori, Djam'an dan Aan Komariah. 2014. Metode Penelitian Kualitatif. Alfabeta : Bandung.

Simmamora, Bilson. 2004. Riset Pemasaran Filsafah, Teori, dan Aplikasi. Gramedia Pustaka Utama : Jakarta.

Simmamora, Bilson. 2005. Analisis Multivariat Pemasaran. Gramedia Pustaka Utama : Jakarta.

Siregar, Syofian. 2010. Statistika Deskriptif untuk Peneliti. PT Rajagrafindo Persada : Jakarta.

Somantri, Ating dan Sambar Ali Muhidin. 2006. Aplikasi Statistika dalam Penelitian. CV Pustaka Setia : Bandung.

Tjiptono, Fandy dan Gregorius Candra. 2005. Service, Quality dan Satisfaction. Andi : Yogyakarta.

Tjiptono, Fandy. 2014. Pemasaran Jasa. Anndi offset : Yogyakarta.

Wijaya, Tony. 2013. Metodologi Penelitian Ekonomi dan Bisnis Teori dan Praktek. Graha ilmu : Yogyakarta 55283.

Yildiz, Emel. 2017. "Effects Of Service Quality On Customer Satisfaction, Trust, Customer Loyalty and Word Of Mouth (An Application On Cargo Companies In Gumushane”. Journal of Economics and Business. Vol.6, No.12: 81-88. 